Egyptian Journal of Rabbit Science, 28 (1): 1- 22(2018)

\title{
PROTECTIVE EFFECT OF CAPSAICIN AGAINST BRAIN OXIDATIVE STRESS INDUCED BY HEAT STRESS IN APRI RABBITS
}

\author{
Kh.A.A. Ali, W. A.H. Ali, A. El-Gamal, M.N.F. Hassanein, T.A. El-Aasar \\ and G.A.G. Mosalm \\ Department of Rabbit Breeding Research, Animal Prod. Res. Inst., Agriculture Reseacher \\ Center, Ministry of Agric., Dokki, Giza, Egypt.
}

Heat stress caused adverse effects which induce oxidative stress and membrane disturbances in brain. Thus, we evaluated the brain oxidative stress induced by heat stress in rabbits with consequent changes in brain neurotransmitters (adrenaline, nor adrenaline and serotonin) and examined the potential protective role of capsaicin against the changes induced by heat stress. Forty eight growing APRI rabbits were used in this study and they were divided into four groups. Rabbits were received oral doses of capsaicin dissolved in $1 \mathrm{ml}$ of corn oil orally three times a week for 7 weeks by using stomach tube, doses were 0 (control), 10, 30 and 50 $\mathrm{mg} / \mathrm{kg}$ body weight for the four groups respectively.

The results indicated that heat stress induce oxidative stress in the brain leading to alterations in the neurochemistry of the brain tissue. On the other hand, heat stress significantly increased the content of lipid peroxidation and decreased the level of non-enzymatic antioxidants and activities of antioxidant enzymes; glutathione peroxidase, superoxide dismutase and catalase and capsaicin treatment significantly decreased the contents of lipid peroxidation and significantly increased glutathione and activities of antioxidant enzymes. Also brain neurotransmitters contents were decreased in control group while capsaicin increased these values in treated group.

Conclusively, capsaicin administration can improve the antioxidant defense systems and brain function during summer season.

Keywords: Capsaicin, lipid peroxidation, GSH, glutathione peroxidase, superoxide dismutase, catalase \& neurotransmitters.

The hypothalamus, is the chief center for regulation of body temperature, utilizes sensory information from external and internal affecters of the body for the thermoregulatory drive. Changing the sensitivity of the warm and/or cold 
sensitive neurons located in the preoptic and anterior hypothalamic ( $\mathrm{PO} / \mathrm{AH})$ may change the threshold for heat production and/or heat loss of the animal. It was reported that serotonin (5-hydroxytryptamine, 5HT) and catecholamines detachment from the Central Nervous System (CNS) play crucial roles in the heat loss and heat production mechanisms in rabbits (White et al., 1985). Also, noradrenaline (NA) or serotonin (5-hydroxytryptamine, 5HT) have a significant impact in PO/AH neuron activities in rabbits (Gordon and Heath, 1981). Changes in catecholamines and serotonin concentrations in various central nervous system regions due to high temperature exposure in newborns and adults are still controversial Some authors reported a decrease (Kregel et al., 1993), an increase (Zhao et al., 2001) and no change in these concentrations (Yuan et al., 1989). In general, there is evidence that high ambient temperature increases plasma concentrations of catecholamines (adrenaline and nor adrenaline) in rats and impulse traffic in sympathetic fibers (Bini et al., 1980). Passive heating sufficient to raise the core temperature by $1.2^{\circ} \mathrm{C}$ also increases circulating levels of catecholamines and cortisol (Powers et al., 1982). Cells generate small amounts of free radicals or reactive oxygen species (ROS) during their normal metabolism. Although low levels of ROS are essential in many biochemical processes, accumulation of ROS may damage biological macromolecules i.e. lipids, proteins, carbohydrates and DNA (Mates et al., 1999). External factors such as heat, trauma, ultrasound, infections, radiations, toxins etc. can lead to increased free radicals and other ROS and may lead to oxidative stress (Halliwell et al., 1992). An increase in free radical formation relative to loss of the antioxidant defense system during heat stress may render liver more susceptible to oxidative damage, leading to their functional inactivation (Das, 2011).

Capsaicin is the pungent principle in red pepper and has been known to cause dose-dependent fall in body temperature due to increased heat loss responses. Capsaicin injected subcutaneously in rats facilitated (PO/AH) warm sensitive neurons, inhibited cold-sensitive neurons, and did not affect thermally insensitive neurons (Nakayamat et al., 1978). After repeated injection of increasing amounts of capsaicin, the hypothermic responses vanished. In these capsaicin-desensitized rats, local heating of the $\mathrm{PO} / \mathrm{AH}$ failed to induce appropriate heat loss responses and the proportion of both warm and coldsensitive neurons in the total population of neurons recorded was reduced to about half the normal value (Hori, 1981). Capsaicin also has antioxidant, iron- 
binding properties and a hypolipidemic effect (Dairam et al., 2008; and Manjunatha and Srinivasan, 2007).

Therefore, the aim of this study is to evaluate the potential protective role of oral administration of capsaicin in relief of rabbits of physiological drawbacks and oxidative stress resulted from exposure to heat stress during summer condition.

\section{MATERIALS AND METHODS}

The present study was carried out at the Rabbitry of El-Serw Station, Animal Production Research Institute, Agricultural Research Center, Egypt. A total number of 48 unsexed weaned APRI rabbits, aged 5 weeks and averaged $664.49 \pm 3$ gm body weight were randomly divided into four experimental groups (12 rabbits in each). Rabbits were received oral doses of capsaicin (CAP) dissolved in $1 \mathrm{ml}$ of corn oil orally three times a week for 7 weeks by using stomach tube, doses were 0 (control), 10,30 and $50 \mathrm{mg} / \mathrm{kg}$ body weight for the four groups respectively.

\section{Housing and feeding:}

All rabbits were housed in galvanized wire $(20 \times 35 \times 40 \mathrm{~cm})$ cages in a well-ventilated building and were kept under the same managerial, hygienic and environmental conditions during summer season (June to August, 2016). The rabbitry internal minimum and maximum ambient temperatures throughout the experimental period were $27.5^{\circ} \mathrm{C}$ and $37.5^{\circ} \mathrm{C}$, and the relative humidity were $45.7 \%$ and $76.5 \%$, respectively. Natural day light was used in this study; it ranged between 14-16 hours per day.

Rabbits were fed with commercial basal pellet diet was formulated to cover the nutrient requirements contained $17 \%$ crude protein, $13.6 \%$ crude fiber, $2.7 \%$ fat and $2500 \mathrm{kcal} / \mathrm{kg}$ and diet were provided with all required vitamins and minerals as recommended by N.R.C.(1977), Clean fresh water was available for rabbits all the time.

\section{Blood analysis:}

At the end of the experiment (12 week of age), $3 \mathrm{ml}$ of blood were withdrawal at 08:00 - 09:00 am from the marginal ear vein under vacuum in clean tubes without heparin, coagulated blood samples were centrifuged for 15 minutes on $4000 \mathrm{rpm}$ and the clear serum was separated and stored in a deep freezer at $-20^{\circ} \mathrm{C}$ until biochemical analysis. 
Blood serum constituents concentrations were spectrophotometerically determined for serum total lipids, triglyceride, total cholesterol (TG), high density lipoprotein (HDL), low density lipoprotein (LDL), activity of aspartate (AST) alanine (ALT) aminotransferases, glucose (GLU), urea-N and creatinine using available commercial kits as described by the manufacturer companies (Spectrum, Diagnostics, Egypt. Co. for Biotechnology, S.A.E).

After slaughtering, the whole brain of each animal was rapidly dissected, thoroughly washed with isotonic saline dried and weighed. Each brain was homogenized immediately to give $10 \%$ (w/v) homogenate in ice-cold medium containing $50 \mathrm{mM}$ Tris-Hcl (pH 7.4) and $300 \mathrm{mM}$ sucrose (Tsakiris et al., 2004). The homogenate was centrifuged at $3000 \mathrm{rpm}$ for $10 \mathrm{~min}$ at $4{ }^{\circ} \mathrm{C}$. The supernatant (10\%) was used for the determination of brain lipid peroxidation, enzymatic and non-enzymatic, antioxidants, adrenaline (AD) noradrenaline (NA) and serotonin (5-HT).

\section{Brain neurotransmitters and antioxidant defense systems estimation:}

Frozen brain samples were homogenized in $30 \mathrm{ml}$ butanol for catecholamine extraction as described by Brownlee and Springgs (1965). This extraction was then transferred to a $125 \mathrm{ml}$ bottle and $2 \mathrm{ml}$ of $0.01 \mathrm{~N} \mathrm{HCI}$ and $5 \mathrm{~g}$ sodium chloride were added. The bottle was then shaken at room temperature with a speed of 50 strokes per minute for one hour. The mixture was then centrifuged at $2000 \mathrm{rpm}$ for $5 \mathrm{~min}$. After extraction, fluorimetric technique was used for estimation of neurotransmitters (NA, AD and 5-HT) levels at excitation and emission wave length on spectrophotometer as described by Ciarlone (1978).

\section{Determination of oxidative stress markers:}

Lipid peroxidation (LPO). Malondialdehyd (MDA) a marker of lipid peroxidation was assayed using thiobarbituric acid reacting substance (TBARS) (Buege and Aust, 1978). MDA level was expressed as nmole/g wet tissue.

\section{Determination of enzymatic antioxidants:}

Superoxide dismutase (SOD; EC 1.15.1.1):

SOD activity was determined by the method of Marklund and Marklund (1974). In this test, the degree of inhibition of pyrogallol auto-oxidation by supernatant of the tissue homogenate was measured. One SOD unit corresponds to the enzyme required to inhibit half of the oxidation of pyrogallol. SOD activity was expressed as U/mg of protein. 
Catalase (CAT; EC 1.11.1.6):

CAT activity was determined according to the method of Aebi (1984). The rate of $\mathrm{H}_{2} \mathrm{O}_{2}$ decomposition was followed by monitoring absorption at 240 $\mathrm{nm}$. One unit of CAT activity is defined as the amount of enzymes required to decompose $1 \mathrm{mmoleol}$ of hydrogen peroxide in $1 \mathrm{~min}$. The CAT activity was expressed as mmole $\mathrm{H}_{2} \mathrm{O}_{2}$ utilized/min/mg protein. CAT activity was expressed as $\mathrm{U} / \mathrm{mg}$ protein.

Glutathione peroxidase (GPx; EC 1.11.1.9):

GPx activity was determined as described by Rotruck et al. (1973). This method depends on determination of the rate of glutathione oxidation by $\mathrm{H}_{2} \mathrm{O}_{2}$ as catalysed by the GPx present in the supernatant. The colour develops is read against a reagent blank at $412 \mathrm{~nm}$. The activity of GPx was expressed in terms of nmole of GSH oxidized/min/mg protein. GPx activity was expressed as U/ mg protein.

\section{Determination of non-enzymatic antioxidants:}

Reduced glutathione (GSH):

Brain GSH content was determined by the method of Ellman (1959) modified by Jollow et al., (1974) based on the development of a yellow colour when 5,5-dithiobis-2-nitrobezoic acid (DTNB), was added to compounds containing sulfhydryl groups. The absorbance was read spectrophotometrically at $412 \mathrm{~nm}$. Total GSH content was expressed as mmole GSH/g of tissue.

\section{Vitamin C (Ascorbic acid):}

Ascorbic acid concentration was assayed as described by Omaye $\boldsymbol{e t} \boldsymbol{a l}$. (1979). A weighted piece of brain tissue was homogenized in trichloroacetic acid and centrifuged at $2000 \mathrm{rpm}$ for $20 \mathrm{~min}$ at $4^{\circ} \mathrm{C}$. DTC reagent (dinitrophenyl hydrazine, thiourea and $\mathrm{Cu} 2+$ ) was added to the supernatant and mixed thoroughly. The tubes were incubated at $37^{\circ} \mathrm{C}$ for 3 hours and to this a solution ice cold $65 \% \mathrm{H}_{2} \mathrm{SO}_{4}$ was added. The resulting colour was read at $520 \mathrm{~nm}$. The results were expressed in $\mu$ mole/g tissue.

\section{Vitamin E ( $\alpha$-Tocopherol):}

A-Tocopherol concentration was assayed as described by Backer et al. (1980). A weighted piece of brain tissue was homogenized in a mixture of petroleum ether and ethanol $(2: 1.6 \mathrm{v} / \mathrm{v})$ and centrifuged at $15,680 \times \mathrm{g}$ for $20 \mathrm{~min}$ at $4{ }^{\circ} \mathrm{C}$ and the supernatant was used for estimation of $\alpha$-tocopherol. To one $\mathrm{ml}$ of 
supernatant, 2\% 2,2-dipyridyl and $0.5 \%$ ferric chloride. The colour developed was read at $520 \mathrm{~nm}$. The values are expressed as nmole/g tissue.

Statistical analysis:

Data were statistically analyzed according to Snedecor and Cochran (1982) using SAS (2001) computer program using the following fixed model :

$$
\mathrm{Yij}=\mu+\mathrm{T}_{\mathrm{i}}+\mathrm{e}_{\mathrm{ij}}
$$

Where: $\mathrm{Y}_{\mathrm{ij}}=$ The observation; $\mu=$ Overall mean; $\mathrm{T}_{\mathrm{i}}=$ Effect of treatments; $\mathrm{e}_{\mathrm{ij}}=$ Random error component assumed to be normally distributed.

Duncan's multiple range tests was performed (Duncan, 1955) to detect significant differences among means.

\section{RESULTS AND DISCUSSION}

\section{Liver functions:}

As shown in Table 1, oral administrations of capsaicin significantly decreased serum AST and ALT compared to control group during summer season. It suggested that elevation of liver enzyme activities may result hepatocellular damage (Mostafa, et al., 2007), which is a combined result of the high temperature and the severely reduced blood supply (Rubel, 1984). The increase observed immediately after heat stress for AST and ALT could be also related to the increase in cortisol levels following stress (Zahran, 2004). In addition, elevation of high ambient temperature could potentially be attributed to the release of these enzymes from the cytoplasm into the blood circulation after rupture of the plasma membrane and cellular damage (Naik and Panda, 2007). Such increased activities might be attributed to the leakage of these enzymes from the injured liver cells into the blood stream because of the altered liver membrane permeability.

On the other hand, administration of capsaicin significantly decreased serum AST and ALT compared to control group during summer season. These results are in agreement with. Sadeek and Abd El-Razek (2010) they found that the incorporation of the turmeric, clove, chili, or cardamom in the diet at $2 \%$ significantly restored the enzyme activities of the liver AST, ALT and ALP to normal level. Capsaicin significantly protects the liver from injury by reducing the activities of serum AST, ALT, and ALP, and by improving the histological architecture of the liver (Bitencourt et al., 2015). Also they demonstrated that capsaicin was effective in preventing and reversing cirrhosis, probably by its 
Table 1: Effect of oral administration of capsaicin on liver and kidney functions in rabbits during summer season.

\begin{tabular}{|l|c|c|c|c|}
\hline \multirow{2}{*}{ Item } & \multicolumn{5}{|c|}{ Capsaicin levels (mg/kg body weight) } \\
\cline { 2 - 5 } & $\mathbf{0}$ & $\mathbf{1 0}$ & $\mathbf{3 0}$ & $\mathbf{5 0}$ \\
\hline \multirow{2}{*}{ AST (U/I) } & $26.52^{\mathrm{a}}$ & $25.32^{\mathrm{b}}$ & $16.97^{\mathrm{c}}$ & $15.25^{\mathrm{c}}$ \\
& \pm 0.26 & \pm 0.26 & \pm 0.28 & \pm 0.30 \\
\hline \multirow{2}{*}{ ALT(U/I) } & $46.75^{\mathrm{a}}$ & $44.72^{\mathrm{b}}$ & $32.03^{\mathrm{c}}$ & $31.71^{\mathrm{c}}$ \\
& \pm 0.38 & \pm 0.25 & \pm 0.49 & \pm 0.34 \\
\hline \multirow{2}{*}{ Urea-N (mg/dl) } & $28.89^{\mathrm{a}}$ & $21.66^{\mathrm{b}}$ & $18.22^{\mathrm{c}}$ & $17.45^{\mathrm{c}}$ \\
& \pm 0.22 & \pm 0.37 & \pm 0.23 & \pm 0.33 \\
\hline \multirow{2}{*}{ Creatinine (mg/dl) } & $2.39^{\mathrm{a}}$ & $1.92^{\mathrm{b}}$ & $1.67^{\mathrm{c}}$ & $1.60^{\mathrm{c}}$ \\
& \pm 0.04 & \pm 0.09 & \pm 0.05 & \pm 0.06 \\
\hline
\end{tabular}

a-c Means within a row with different superscripts are significantly differ at $(\mathrm{P} \leq 0.05)$.

ability of reducing transforming growth factor-beta (TGF-beta) expression. Thus capsaicin might be an effective antifibrotic and fibrolitic drug in the treatment of chronic hepatic diseases.

The effect of capsaicin on prevention of acute liver damage can be explained by at least two mechanisms: acting as an antioxidant and by inhibiting nuclear factor $-\kappa \mathrm{B}(\mathrm{NF}-\kappa \mathrm{B})$ activation and thus production of proinflammatory cytokines (Gupta et al., 2010). The treated with capsaicin effectively decreased liver enzyme levels in the serum. This can be attributed to the presence of capsaicin as antioxidant which contains phenolic compounds that can act by scavenging free radicals (Sadeek and Abd El-Razek., 2010).

Capsaicin can be effectively absorbed after and reach liver tissue and hepatobiliary tree at concentrations sufficient to excite sensory nerve endings (Abdel-Salam et al. 2005). Capsaicin given orally to rats decreased hepatic injury caused by CCl4 (Abdel-Salam et al. 2006). It is also conceivable that the increase in hepatic GSH and reduction in serum nitric oxide might contribute to the protective effects of capsaicin observed in that study.

\section{Kidney functions:}

Data presented in Table 1, showed that a significant increase of serum urea-N and creatinine levels in control group as compared to capsaicin groups during summer season. High means of urea and creatinine of control group are in agreement with results of previous studies in animals (Gudev and colleagues, 2010) who suggested that increasing plasma urea-N level in heat stressed animals closely related with the dynamic of cortisol and blood volume fluctuation in animals under heat. Also, Holthoff et al. (2010) investigated that 
oxidant damage from reactive oxygen species (ROS) and reactive nitrogen species (RNS) during heat stress is a major contributor to the cellular damage seen in numerous types of renal injury. Subsequently, the antioxidant properties of capsaicin are of particular interest because of the fundamental role in alleviating oxidant damage. On the other hand, Liu and Nair (2010) found that capsaicin, could reduce the level of lipid peroxides in rats suffering from cisplatin-induced nephrotoxicity. Capsaicin works as a protection of different tissue from oxidative damage because its ability antioxidant capacity (Kogure et al., 2002).

\section{Lipid Profile}

Under heat stress, rabbits in treated groups showed a significant reduction in plasma TL and TG concentrations values comparing with control group value. A similar trend was observed with plasma cholesterol concentration, which significant reduced for rabbits $r$ rabbits administrated with capsaicin than the control. Serum LDL concentration was gradually and significantly reduced in treated rabbits with capsaicin than the control group, while serum HDL concentration was increased than the control and this effect was significant at any capsaicin dose (Table 2). These results are in concordance with those of Salem et al. (1998) who reported that plasma cholesterol concentrations were significantly higher during the summer compared to the winter, which could reflect increase of total lipid content in the heat-stressed rabbits in our results.

These findings also are in agreement with previous studies, which have shown an inverse correlation between dietary capsaicin and the concentrations of plasma cholesterol and triglycerides. Zhang et al. (2007) found that plasma triglycerides levels were significantly decreased in mice on a high fat diet plus capsaicin compared with that of mice on a high fat diet. Kawada et al. (1986) reported that capsaicin supplemented diet reduced the level of serum triglyceride but not serum total cholesterol. Moreover, the amounts of total lipid and triglycerides in the liver were also lower in capsaicin-treated rats compared to control (Ji Young et al., 2011). Manjunatha and Srinivasan (2007) reported that capsaicin supplementation decreased the levels of serum total cholesterol and triglyceride, and hepatic triglyceride. Negulesco et al. (1987) have observed that administration of $8 \mathrm{mg}$ capsaicin/day for 35 days to rabbits on a $0.5 \%$ cholesterol diet produced a beneficial lowering of plasma cholesterol and triglycerides. According to Srinivasan and Sambaiah (1991) suggested that the cholesterollowering effects of capsaicin stem in part from activation of hepatic cholesterol 
$7 \alpha$-hydroxylase, the rate-limiting enzyme converting cholesterol to bile acids, which is an important pathway for eliminating cholesterol from the body. Capsaicin supplementation decreased activity of glycerol-3-phosphate dehydrogenase (GPDH) in white adipose tissue and, the inactivation of GPDH may have led to the decreased amounts of white adipose tissue in rats treated with capsaicin (Ji Young et al., 2011).

\section{Blood glucose}

It was clearly evident from (Table 2) that oral administration of capsaicin significantly decreased serum glucose, especially at 30 and $50 \mathrm{mg} / \mathrm{kg}$ body weight groups. This result is in an agreement with Kang et al. (2010) dietary capsaicin decreased glucose (GLU) levels in the plasma.

This result may explained by the fact that Capsaicin is the main component of chilli inhibits the intestinal absorption of glucose and this justifies the hypoglycaemic effect of chilli as pointed by Al-Kassie et al. (2011), subsequently, the lower circulatory glucose concentration in the capsaicin supplemented birds was perhaps indicative of an increased turnover rate and utilization of glucose at the tissue level. On the other hand, capsaicin has been attributed to increased energy expenditure by activation of the sympathetic nervous system, induction of norepinephrine (NE) release, stimulation of $\beta$ adrenoceptors and enhancement lipid and glucose metabolism (Ding et al., 2016).

\section{Lipid peroxidation}

It was apparent from (Table 3) that there was significant increase in lipid peroxidation product, malonaldehyde (MDA) in brain homogenate in control group compared with capsaicin groups during summer season. Our results agree with (Kwiecien et al., 2003) who reported that capsaicin induced a complicated expressive pattern of both oxidative stress genes as well as antioxidant defense genes. Oxidative stress, as reflected by an increase of MDA and 4-HNE tissue concentrations (an index of lipid peroxidation), as well as decrease of SOD activity. The protective effect of capsaicinoid on lipid peroxidation in rat tissues, whereas levels of total lipids and concentrations of malondialdehyde (MDA) were reduced in the group that received hot red pepper (Rosa et al., 2005). Also, Luqman and Rizvi., (2006), investigated the antioxidative property of capsaicin (8-methyl-N-vanillyl-6-nonemide) found in hot peppers reported reduced oxidative stress; membrane lipid peroxidation (formation of malondialdehyde) 
Table 2: Effect of oral administration of capsaicin on lipid profile and glucose levels $(\mathrm{mg} / \mathrm{dl})$ in rabbits during summer season.

\begin{tabular}{|l|c|c|c|c|}
\hline \multirow{2}{*}{ Item } & \multicolumn{4}{|c|}{ Capsaicin levels (mg/Kg body weight) } \\
\cline { 2 - 5 } & $\mathbf{0}$ & $\mathbf{1 0}$ & $\mathbf{3 0}$ & $\mathbf{5 0}$ \\
\hline \multirow{2}{*}{ Total lipid } & $540.93^{\mathrm{a}}$ & $502.57^{\mathrm{b}}$ & $330.62^{\mathrm{c}}$ & $322.88^{\mathrm{c}}$ \\
& \pm 1.27 & \pm 2.56 & \pm 2.56 & \pm 0.24 \\
\hline \multirow{2}{*}{ Cholesterol } & $113.48^{\mathrm{a}}$ & $108.51^{\mathrm{b}}$ & $78.49^{\mathrm{c}}$ & $77.73^{\mathrm{c}}$ \\
& \pm 0.56 & \pm 0.46 & \pm 0.53 & \pm 0.48 \\
\hline \multirow{2}{*}{ Triglycerides } & $89.74^{\mathrm{a}}$ & $87.44^{\mathrm{b}}$ & $70.61^{\mathrm{c}}$ & $69.42^{\mathrm{c}}$ \\
\hline High density & \pm 0.28 & \pm 0.52 & \pm 0.18 & \pm 0.21 \\
lipoprotein & $30.22^{\mathrm{c}}$ & $30.76^{\mathrm{c}}$ & $36.45^{\mathrm{b}}$ & $40.29^{\mathrm{a}}$ \\
\hline Low density & \pm 0.13 & \pm 0.31 & \pm 0.51 & \pm 0.16 \\
lipoprotein & $102.48^{\mathrm{a}}$ & $99.21^{\mathrm{b}}$ & $81.09^{\mathrm{c}}$ & $79.51^{\mathrm{c}}$ \\
\hline \multirow{2}{*}{ Glucose } & \pm 0.39 & \pm 0.23 & \pm 0.53 & \pm 0.30 \\
\hline
\end{tabular}

a-c Means within a row with different superscripts are significantly differ at $(\mathrm{P} \leq 0.05)$.

Table 3: Effect of oral administration of capsaicin on lipid peroxidation and enzymatic antioxidants of brain rabbits during summer season.

\begin{tabular}{|l|c|c|c|c|}
\hline \multirow{2}{*}{ Item } & \multicolumn{4}{|c|}{ capsaicin levels (mg/kg body weight) } \\
\cline { 2 - 5 } & 0 & 10 & 30 & 50 \\
\hline \multirow{2}{*}{ MDA(nmole/g tissue) } & $33.47^{\mathrm{a}}$ & $31.17^{\mathrm{b}}$ & $20.72^{\mathrm{c}}$ & $18.56^{\mathrm{c}}$ \\
& \pm 0.26 & \pm 0.34 & \pm 0.17 & \pm 0.25 \\
\hline \multirow{2}{*}{ GPx (U/mg protein) } & $73.59^{\mathrm{d}}$ & $80.14^{\mathrm{c}}$ & $91.76^{\mathrm{b}}$ & $97.01^{\mathrm{a}}$ \\
& \pm 0.72 & \pm 0.22 & \pm 0.99 & \pm 0.54 \\
\hline \multirow{2}{*}{ SOD (U/mg protein) } & $2.36^{\mathrm{c}}$ & $2.96^{\mathrm{c}}$ & $3.94^{\mathrm{b}}$ & $4.29^{\mathrm{a}}$ \\
& \pm 0.08 & \pm 0.05 & \pm 0.11 & \pm 0.06 \\
\hline \multirow{2}{*}{ CAT (U/mg protein) } & $61.59^{\mathrm{c}}$ & $65.37^{\mathrm{b}}$ & $84.79^{\mathrm{a}}$ & $86.11^{\mathrm{a}}$ \\
& \pm 0.64 & \pm 0.90 & \pm 0.71 & \pm 0.10 \\
\hline
\end{tabular}

a-d Means within a row with different superscripts are significantly differ at $(\mathrm{P} \leq 0.05)$. Malondialdehyd (MDA) - Glutathione peroxidase (GPx) - Superoxide dismutase (SOD) - Catalase (CAT).

and membrane carbonyl groups in human erythrocytes. On the other side, Dairam et al. (2008) investigated the antioxidant and metal-binding properties of curcumin and capsaicin which are major components in turmeric and chili 
respectively which works readily scavenge free radicals. These spice ingredients turmeric and chili significantly curtail iron- $(\mathrm{Fe} 2+)$ and quinolinic acid (QA)induced lipid peroxidation. Capsaicin treatment has shown a marked protection on the content of Thiobarbituric acid reactive substances (TBARS). This may be due to the presence of phenolic component, which works scavenger of free radicals, thereby inhibiting lipid peroxidation and thus in agreement with the findings of Shimeda et al., (2005). On the other hand, the antioxidant activity of capsaicin could be attributed to its phytochemical contents which increases the amount or increase the activity of antioxidant enzymes (Sadeek and Abd ElRazek., 2010).

\section{Enzymatic antioxidants}

It was clearly evident from (Table 3 ) that oral administration of capsaicin afforded a highly significant increase $(\mathrm{P} \leq 0.05)$ in antioxidant enzymes levels compared with control group during summer season. It is widely accepted that the induction of anti-oxidant enzymes are a major strategy for protecting cells against a variety of endogenous and exogenoustoxic compounds such as ROS (Ozen and Korkmaz 2003). Activities of the antioxidant enzymes SOD, CAT and GPx, were observed to be lowered in control group during summer season. This reduction in antioxidant enzyme activities which could be attributed to the decreased in synthesis of enzyme proteins. Such phenomenon is due to that environmental temperature stimulates the peripheral thermal receptors to transmit suppressive nerve impulses to the appetite centre in the hypothalamus causing the decrease in feed consumption, i.e. dry matter intake and consequently fewer substrates become available for enzymatic and hormone synthesis (Kamal, 1975). Young and Woodside (2001) added that, ROS promote destruction in neuronal lipid associated with modifications in the enzymatic antioxidant defense system, therefore, having severe actions on the structural integrity, progressing as well functional of the neurons of central nervous system resulting in antioxidants diminution.

Treated with capsaicin capsaicin lead to the activities of these enzymes was markedly elevated in these groups. This may be due to the direct reaction of capsaicin with superoxide, hydroxyl and alkoxyl radicals, which in turn reduces free radical formation and oxidative damage during heat stress. These antilipoperoxidative properties of capsaicin may be attributed to the remarkable enhancement of glutathione peroxidase, glutathione reductase, superoxide dismutase, and catalase activities in the rabbits. Our results are in agreement with results of Sadeek and Abd El-Razek. (2010) they found that the antioxidant 
activity of capsaicin could be attributed to increase the amount or increase the activity of antioxidant enzymes.

\section{Non-enzymatic antioxidants}

Heat stress was found to increase the production of free radicals after 12, 16 and 18-hours $\left(26 \mathrm{vs} 35^{\circ} \mathrm{C}\right)$ of heat stress in skeletal muscle (Young et al., 2013). In the present study, a decline was observed in GSH levels in control group during summer season, the reduction in GSH level in brain tissue of rabbits with heat stress may be explained on the basis of elevated $\mathrm{H}_{2} \mathrm{O}_{2}$ cytotoxicity in endothelial cells as a consequence of glutathione reductase inhibition. The treatment with CAP, lead to elevated GSH levels in these groups during summer season (Table 4).

Vitamin C, an important antioxidant, acts in tissues, involving ROS in aqueousphase and it has been reported that the tissue concentration of vitamin $\mathrm{C}$ is a good indicator of oxidative stress (Frei et al. , 1989). Vitamin E is a principal lipid soluble antioxidant in cell membranes that protect cellular structures against oxidative damage (Komburst and Mavis, 1980). The concentration of vitamin E has been inversely correlated to LPO (Selvendiran and Sakthisekaran, 2004). Vitamin $C$ and $E$ levels were decreased in control groups during summer season. The levels of these vitamins in rabbits challenged and were almost normalized with treated by CAP. The results are in agreement with the previous finding (Kempiah and Srinivasan, 2004) which reported that CAP was effective against oxidative stress by countering the depleted antioxidant molecules and antioxidant enzymes.

It is well documented that CAP scavenges radical sat/near the membrane surface and in the interior of the membranes and these dual effects of CAP could be responsible for its potent antiperoxidation activity (Kogure et al., 2002). Hence, the role of CAP as a free radical quencher and its role in maintaining the tissue antioxidant status are apparent from our studies. Kogure et al. (2002) have found that the C-7 benzyl carbon, but not the phenolic OH group of capsaicin, is responsible for the scavenging site. Additionally, they found vanillin and 8-methyl-6-noneamide as products of capsaicin oxidative decomposition. On the other hand, the antioxidant behavior for capsaicin was due primarily to the phenolic moiety in the molecule, (Henderson et al., 1999).

\section{Neurotransmitters:}

Data presented in Table 5, indicated that oral administrations of capsaicin at different levels led to increase significant in adrenaline and serotonin content 
Table 4: Effect of oral administration of capsaicin on non-enzymatic antioxidants of brain rabbits during summer season.

\begin{tabular}{|c|c|c|c|c|}
\hline \multirow{2}{*}{ Item } & \multicolumn{4}{|c|}{ Capsaicin levels (mg/kg body weight) } \\
\cline { 2 - 5 } & 0 & 10 & 30 & 50 \\
\hline \multirow{2}{*}{ GSH (nmole/g tissue) } & $0.84^{\mathrm{d}}$ & $0.96^{\mathrm{c}}$ & $1.36^{\mathrm{b}}$ & $1.55^{\mathrm{a}}$ \\
& \pm 0.01 & \pm 0.01 & \pm 0.01 & \pm 0.05 \\
\hline \multirow{2}{*}{ AA ( $\boldsymbol{\mu m o l e / g ~ t i s s u e ) ~}$} & $61.59^{\mathrm{d}}$ & $65.93^{\mathrm{c}}$ & $92.68^{\mathrm{b}}$ & $95.49^{\mathrm{a}}$ \\
& \pm 0.41 & \pm 0.33 & \pm 0.69 & \pm 0.90 \\
\hline \multirow{2}{*}{ V.E (nmole/g tissue) } & $24.27^{\mathrm{d}}$ & $26.83^{\mathrm{c}}$ & $33.05^{\mathrm{b}}$ & $35.97^{\mathrm{a}}$ \\
& \pm 0.40 & \pm 0.21 & \pm 0.34 & \pm 0.22 \\
\hline
\end{tabular}

a-c Means within a row with different superscripts are significantly differ at $(\mathrm{P} \leq 0.05)$.

Reduced glutathione (GSH) - Ascorbic acid (AA) - Vitamin E ( $\alpha$-Tocopherol).

Table 5: Effect of oral administration of capsaicin on neurotransmitters content of brain rabbits during summer season.

\begin{tabular}{|l|c|c|c|c|}
\hline \multirow{2}{*}{ Item } & \multicolumn{4}{|c|}{ Capsaicin levels (mg/Kg body weight) } \\
\cline { 2 - 5 } & 0 & 10 & 30 & 50 \\
\hline \multirow{2}{*}{ Serotonin (ng/g tissue) } & $24.27^{\mathrm{d}}$ & $26.83^{\mathrm{c}}$ & $33.05^{\mathrm{b}}$ & $35.97^{\mathrm{a}}$ \\
& \pm 0.40 & \pm 0.21 & \pm 0.34 & \pm 0.22 \\
\hline \multirow{2}{*}{ Adrenalin (ng/g tissue) } & $167.58^{\mathrm{d}}$ & $170.72^{\mathrm{c}}$ & $256.20^{\mathrm{b}}$ & $276.20^{\mathrm{a}}$ \\
& \pm 0.59 & \pm 0.20 & \pm 0.44 & \pm 0.69 \\
\hline \multirow{2}{*}{ Noradrenalin (ng/g tissue) } & $111.77^{\mathrm{b}}$ & $111.94^{\mathrm{b}}$ & $155.21^{\mathrm{a}}$ & $155.94^{\mathrm{a}}$ \\
& \pm 0.40 & \pm 0.51 & \pm 0.64 & \pm 0.38 \\
\hline
\end{tabular}

a-c Means within a row with different superscripts are significantly differ at $(\mathrm{P} \leq 0.05)$.

of the brain for these groups compared with control group during summer season. Nevertheless, the noradrenaline content of the brain was significantly increased in 30 and $50 \mathrm{mg} / \mathrm{kg}$ body weight groups compared with other groups during summer season. Heat exposure led to increase concentrations of plasma and changes in the cells of adrenal gland medulla in the rats (Petrovic-Kosanovic et al., 2012). Also, Yuan et al. (1989) found that heat exposure for $15 \mathrm{~min}$ at $45^{\circ} \mathrm{C}$ reduced the brain content of noradrenaline (NA) in mice. The general decrease of monoamine concentrations in various regions of the CNS for the heat stressed rats may be resulted to the increase of the degradative enzyme or monoamine oxidase activity (Ma et al., 2004). The decrease may be also attributed to the reduced activity or the suppression of de novo-synthesis of enzymes involved in the formation of NA. This proposition was supported by the findings of Miller and Callaghan (1995) and Fleckenstein (1997) who found 
that hyperthermia decreased the activity of key enzymes responsible for catecholamines and serotonin formation like tyrosine hydroxylase and tryptophan hydroxylase. Another possible explanation that the depletion of monoamine content in the CNS regions may be due to the histological lesions like gliosis, oedema, vacuolation and necrosis and delay in the neurogenesis and dendritic arboryzation development as a result of heat stress (Ahmed, 2004). Thus, it has been proposed that interestingly, polyphenol capsaicin is absorbed from the intestinal tract into the circulation and is detectable in brain tissues (Del Rio et al., 2010). It is well known the protein vanilloid receptor 1 (VR1) is involved in sensory transduction in the peripheral nerve endings of sensory neurones. It can be activated by elevations in temperature, or by exogenous ligands such as capsaicin (Caterina et al. 1997 and Tominaga et al. 1998) and therefore, VR1 receptor activation may influence the release of diverse neurotransmitters in many parts of the CNS (Al-Hayani et al., 2001) .

The neuroprotective effects of polyphenol capsaicin may be mediated through the protection of tricarboxylic acid cycle enzymes from free radicals attack and maintenance of mitochondrial energy production levels (Choi et al., 2012). At the same time, noradrenaline decreases lipid peroxide production in the brown adipose tissue (BAT) only (Andorn and Pappolla, 2001). Also, this is in agreement with the findings of Sergeev et al. (1975) who found that some catecholamines, noradrenaline among of them, inhibit lipid peroxidation and have antioxidant action. This noradrenaline antioxidant action was associated with the presence of a free phenol group in their molecule. The mechanism of inhibition is the interaction of catecholamines with the free radicals leading of the oxidation chain.

Conclusively, the present results showed that the chemopreventive role of capsaicin during heat stress could be by modulating reactive oxygen species and sustaining the brain antioxidant defense system.

\section{REFERENCES:}

Abdel-Salam, O.M.E.; A.A. Sleem; N.S. Hassan; H.A. Sharaf and G.Y. Mozsik (2006). Capsaicin ameliorates hepatic injury caused by carbon tetrachloride in the rat. J. Pharmacol. Toxciol.; 1(2): 147-156.

Abdel-Salam, O.M.E; O.A. Heikal and S.M. El-Shenawy (2005). Effect of capsaicin on bile secretion in the rat. Pharmacology; 73: 121-128. 
Aebi, H. (1984). Catalase in vitro. Methods in Enzymology; 105:121-126.

Ahmed, R.G. (2004). Effect of heat stress on the development of the nervous system in Albino rats. M.Sc. Thesis. Beni-Suef Branch; Cairo University; Egypt.

Al-Hayani, A.; K.N. Wease; R.A. Ross; R.G. Pertwee and S.N. Davies (2001). The endogeno us cannabinoid anandamide activates vanilloid receptors in the rat hippocampal lice. Neuropharmacology. ; 41:1000 1005.

Al-Kassie, G.A.M.; A.M.A. Mamdooh and J.A. Saba (2011). The effects of using hot red pepper as a diet supplement on some performance traits in broiler. Pakistan Journal of Nutrition.; 9: 842-845.

Andorn, A.C. and M.A. Pappolla (2001). Catecholamines inhibit lipid peroxidation in young; aged and Alzheimer's disease. Free Rad Biol Med; 31: 315-320.

Backer, H.; O. Frank; B. De Angells and S. Feingold (1980). Plasma tocopherol in man at various times after ingesting free or ocetylaned tocopherol. Nutrition Reports International; 21: 531-536.

Bini, G.; K.E. Hagbarth; P. Hynninen; B.G. Wallin (1980). Regional similarities and differences in thermoregulatory vaso- and sudomotor tone. J. Physiol.; 306: 553-565.

Bitencourt, S.; L. Stradiot; S. Verhulst; L. Thoen; I. Mannaerts; L.A. and Van Grunsven (2015). Inhibitory effect of dietary capsaicin on liver fibrosis in mice. Mol. Nutr Food Res. Jun; 59 (6): 1107-1116.

Brownlee, G. and T.L.B. Springgs (1965). Estimation of dopamine, noradrenaline, adrenaline and 5-Hydroxytryptamine from single rat brains. J. Pharm. Pharmacol.; 17: 429-433.

Buege, J.A. and S.D. Aust (1978). Microsomal lipid peroxidation. Methods Enzymol.;52:302-10.

Caterina, M.J.; Schumacher M.A.; Tominaga M.; Rosen T.A.; Levine J.D. and D. Julius 1997. The capsaicin receptor: a heat-activated ion channel in the pain pathway. Nature; 389: 816-824.

Choi, D.Y; Y.J, Lee; J.T. Hong and H.J. Lee (2012). Antioxidant properties of natural polyphenols and their therapeutic potentials for Alzheimer's disease. Brain Res Bull; 87:144-53.

Ciarlone, A.F. (1978). Further modification of a fluorometric method for analyzing brainamines. Microchemical Journal.; 23:9-12. 
Cronin, J.G; M.L. Turner; L. Goetze; C.E. Bryant; and I.M. Sheldon (2012). Toll-like receptor 4 and MYD88-dependent signaling mechanisms of the innate immune system are essential for the response to lipopolysaccharide by epithelial and stromal cells of the bovine endometrium. Biol. Reprod.; 86: 51.

Dairam, A.; R. Fogel; S. Daya and J.L. Limson (2008) Antioxidant and iron-binding properties of curcumin; capsaicin; and S-allylcysteine reduce oxidative stress in rat brain homogenate. Journal of Agricultural and Food Chemistry, 56(9): 3350-3356.

Das, A (2011). Heat stress-induced hepatotoxicity and its prevention by resveratrol in rats. Toxicol Mech Methods. Jun; 21(5):393-399.

Del Rio, D; G. Borges and A.Crozier (2010). Berry flavonoids and phenolics: bioavailability and evidence of protective effects. Br. J. Nutr; 104:67-90.

Ding, L. ; F. Zhang; M.X. Zhao; X.S. Ren; Q. Chen; Y.H. Li; Y.M. Kang; and G.Q. Zhu (2016). Reduced lipolysis response to adipose afferent reflex involved in impaired activation of adrenoceptor-cAMP-PKAhormone sensitive lipase pathway in obesity. https://www .ncbi. nlm. nih. Gov /pmc/articles/PMC5046068/

Duncan, D.B.; (1955). Multiple range and multiple F tests. Biometrics ;1:142.

Ellman, G.L. (1959). Tissue sulfhydryl groups. Arch. Biochem.; 82: 70-77.

Fleckenstein, A.E. (1997). Effect of methamphetamine on tryptophan decarboxylase activity: Role of hyperthermia. Eur. J. Pharmacol.; 332: 263-265.

Frei. B.; L. England and B. N. Ames (1989). Ascorbate is outstanding antioxidant in human plasma. Proceedings of the National Academy of Sciences; 86 (16):6377-6381.

Gordon, C. J. and J. E. Heath (1981). Effect of monoamines on firing rate and thermal sensitivity of neurons in the preoptic area of awake rabbits. Expl. Neurol.; 72: 352-365.

Gudev, D.; Popova-Ralcheva; S. ; Moneva; P.; Aleksiev; Y.; Peeva; T.; Ilieva; Y. and P. Penchev (2010). Effect of heat-stress on some physiological and biochemical parameters in buffaloes. Italian J. Anim. Sci.; 6 (2): 1325-1328. 
Gupta, S.C; C. Sundaram; S. Reuter; and B.B. Aggarwal (2010). Inhibiting NF-kappaB activation by small molecules as a therapeutic strategy. Biochimica et Biophysica Acta, (PMC free article).

Halliwell, B.; J.M.C. Gutteridge and C.E. Cross (1992). Free radicals; antioxidants and human diseases: Where are we now? J. Lab. And Clin. Med.; 119(6): 598-620.

Henderson, D.E.; A.M. Slickman and S.K. Henderson (1999). Quantitative HPLC determination of the antioxidant activity of capsaicin on the formation of lipid hydroperoxides of linoleic acid: a comparative study against BHT and melatonin. J. Agric. Food Chem.; 47: 2563-2570.

Holthoff, J.H.; K.A. Woodling; D.R. Doerge; S.T. Burns; J.A. Hinson and P.R. Mayeux (2010). Resveratrol; a dietary polyphenoli phytoalexin; is a functional scavenger of peroxynitrite. Biochem. Pharmacol.; 80 (8): 1260-1265.

Hori, T. (1981). Thermosensitivity of preoptic and anterior hypothalamic neurons in the capsaicin-desensitized rat. P. Flugers Arch.; 389: 297-299.

Ji Young, Ann; Mak-Soon Lee; Hyunjin Joo; Chong-Tai Kim; and Yangha Kim (2011). Reduction of Body Weight by Capsaicin is Associated with Inhibition of Glycerol-3-Phosphate Dehydrogenase Activity and Stimulation of Uncoupling Protein 2 mRNA Expression in Diet-induced Obese Rats. J. Food. Sci. Nutr.; Vol. 16: p 210-216.

Jollow, D.J.; J.R. Mitchell; Z. Zamppaglione and J.R. Gillette (1974). Bromobenzene induced liver necrosis. Protective role of glutathione and evidence for 3;4-bromobenzene oxide as the hepatotoxic metabolites; Pharmacol.; 11: 151-157.

Kamal, T.H. (1975). Heat stress concept and new tracer methods for heat tolerance in domestic animals. Proceedings of $1^{\text {st }}$ Scientific Conference on Peaceful Uses of Atomic Energy for Scientific and Economic Development. Atomic Energy Commission; Baghdad; Iraq.

Kang, J.H; T. Goto; I.S. Han; T. Kawada; Y.M. Kim and R. Yu (2010). Dietary capsaicin reduces obesity-induced insulin resistance and hepatic steatosis in obese mice fed a high-fat diet. Obesity (Silver Spring). Apr.;18(4):780-7.

Kawada T; H. agihara; K. Iwai (1986). Effects of capsaicin on lipid metabolism in rats fed high fat diet. J. Nutr.; 116: 1272-1278. 
Kempaiah, R. and K. Srinivasan (2004). Influence of dietary curcumin; capsaicin and garlic on the antioxidant status of red blood cells and the liver in high-fat-fed rats. Annals of Nutrition and Metabolism; 48 (5):314-20 •

Kogure, K; S. Goto; M. Nishimura (2002). Mechanism of potent antiperoxidative effect of capsaicin. Biochim Biophys Acta; 1573: 84-92

Komburst, D.J. and R.D. Mavis (1980). Relative susceptibility of microsomes from lung; heart; liver; kidney; brain andtestes to lipid peroxidation. Correlation with vitamin Econtents. Lipids.; 15: 315-322

Kregel, K.C.; D.G. Johnson and D.R. Seals; (1993). Tissue specific noradrenergic activity during acute heat stress in rats. J. Applied Physiol.; 74: 1988-1993.

Kwiecień, S.; T. Brzozowski; P.C. Konturek; M.W. Pawlik; W.W. Pawlik N. Kwiecień and S.J. Konturek (2003). The role of reactive oxygen species and capsaicin-sensitive sensory nerves in the pathomechanisms of gastric ulcers induced by stress. J. Physiol Pharmacol. Sep. ;54 (3) :423-37.

Liu, Y. and M.G. Nair (2010). Capsaicinoids in the hottest pepper Bhut Jolokia and its antioxidant and nti-inflammatory activities. Nad. Prod. Commun.; 5 (1) : 91-94.

Luqman, S. and S.I. Rizvi (2006). Protection of lipid peroxidation and carbonyl formation in proteins by capsaicin in human erythrocytes subjected to oxidative stress. Phytother. Res.; 20 (4): 303-306.

Ma, J.; M. Yoshimura; E. Yamashita; A. Nakagawa; A. Ito and T. Tsukihara (2004). Structure of rat monoamine oxidase A and its specific recognitions for substrates and inhibitors. J. Mol. Biol.; 338: 103-114.

Manjunatha, H. and K. Srinivasan (2007). Hypolipidemic and antioxidant effects of dietary curcumin and capsaicin in induced hypercholesterolemic rats. Lipids , 42 (12): 1133-1142.

Marklund, S. and G. Marklund (1974). Involvement of the superoxide anion radical in the autoxidation of pyrogallol and a convenient assay for superoxide dismutase. Eur. J. Biochem.; 47:469-74.

Mates, J.M.; C. Perez-Gomez; I. N. De Castro (1999). Antioxidant enzymes and human diseases. Clin. Biochem.; 32:595-603.

Miller, D.B. and J.P. O'Callaghan (1995). The role of temperature; stress and other factors in the neurotoxicity of substituted amphetamines 3,4methylenedioxymethaphetamine and fenfluramine. Mol. Neurobiol.; 11: 177-192. 
Nakayama, T, j.; M. Suzuki; Y. Ishikawa and A. Nishio (1978). Effects of capsaicin on hypothalamic thermo-sensitive neurons in the rat. Neurosci. Lett.; 7:151-155.

Negulesco, J.A.; S.A. Noel; H.A. Newman; E.C. Naber; H.B. Bhat and D.T.Witiak; (1987). Effect of pure capsaicinoids (capsaicin and dihydrocapsaicin) on plasma lipids and lipoprotein concentration of turmey poults. Atherosclerosis, 61: 85-90.

NRC (1977). National Research Council: Nutrient Requirements of Rabbits. $2^{\text {nd }}$ Revised Edition, National Academy of Sciences, Washington, DC. USA.

Omaye S.T.; J.D. Turnbull and H.E. Sauberlich (1979). Selected methods for the determination of ascorbic acid in animal cells; tissues and fluids. Method Enzymol; 62:3-11.

Ozen T. and H. Korkmaz (2003). Modulatory effect of Urtica dioica L (Urticaceae) leaf extract on biotransformation of enzyme systems; antioxidant enzymes; LDH and lipid peroxidation in mice. Phytomedicine; 10 (5):405-415 .

Petrovic-Kosanovic, D.; C. M. Maja ; B. Mirela and K. Vesna (2012). Effect of acute heat stress on rat adrenal medulla - a morphological and ultrastructural study. Central European Journal of Biology, Volume 7; Issue 4; pp: 603-610.

Powers S.K.; E.T. Howley; R. Cox; (1982). Differential catecholamine response during prolonged exercise and passive heating; Med. Sci. Sports Exerc.; 14: 435-439.

Rosa, A.; M. Deiana; G. Corona; A. Atzeri; A. Incani; G. Appendino and M.A. Dessì (2005). Protective effect of capsinoid on lipid peroxidation in rat tissues induced by Fe-NTA. Free Radic.; 39 (11): 1155-1162.

Rotruck, J.T; A.L. Pope; H.E. Ganther; A.B. Swanson; D.G. Hafeman and W.G. Hoekstra (1973). Selenium: Biochemical role as a component of glutathione peroxidase. Sciences; 179 : 588-590.

Sadeek, Eman A. and Fatma H. Abd El-Razek (2010). The ChemoProtective Effect of Turmeric, Chili, Cloves and Cardamom on Correcting Iron Overload-Induced Liver Injury; Oxidative Stress and Serum Lipid Profile in Rat Models. Journal of American Science: 6 (10): 702-712.

Salem, I.A.; M.A. Kobeisy; M. Zenhom and M. Hayder (1998). Effect of season and ascorbic acid supplementation on some blood constituents of suckling Chios lambs and its crosses with Ossimi sheep in upper Egypt. Assiut Journal of Agriculture Science, 29: 87-100. 
SAS, (2001). SAS User's guide: Statistics; Version $9^{\text {th }}$ Ed. SAS Institute Inc.; Cary N.C.; USA.

Selvendiran, K. and D. Sakthisekaran (2004). Chemopreventive effect of piperine on modulating lipid peroxidation and membrane bound enzymes in benzo(a) pyrene induced lung carcinogenesis. Biomedecine \& Pharmacotherapy; 58 (4): 264-7.

Sergeev P.V.; R.D. Seifulla; V.G. Dunaev and I.N. Rudnev (1975). Effect of adrenaline; noradrenaline; dopamine; DOPA and phenylalanine on lipid peroxidation in liver mitochondria membranes. Bull. Eksp. Biol .Med. , 80: 25-28.

Shimeda, Y.; Y. Hirotani; Y. Akimoto; Y. Shindou; K. Ijiri; T. Nishihoriand K.T. Tanaka (2005). Protective effects of capsaicin against caspcacin-induced nephrotoxicity in rats. Biological and Pharmaceutical Bulletin, 28; 635-1638.

Srinivasan, K. and K. Sambaiah (1991). The effect of spices on cholesterol 7 alpha-hydroxylase activity and on serum and hepatic cholesterol levels in the rat. Int. J. Vitam. Nutr. Res., 61: 364-369.

Tominaga, M.; M.J. Caterina; A.B. Malmberg; T.A. Rosen; H. Gilbert; K. Skinner; B.E. Raumann; A.I. Basbaum and D. Julius (1998). The cloned capsaicin receptor integrates multiple pain-producing stimuli. Neuron, 21:531-543

Tsakiris, S; K.H. Schulpis; K. Marinou and P. Behrakis (2004). Protective effect of l-cysteine and glutathione on the modulated suckling rat brain $\mathrm{Na}+\mathrm{K}+-\mathrm{ATPase}$ and $\mathrm{Mg} 2+-\mathrm{ATPase}$ activities induced by the in vitro galactosaemia. Pharmacol Res.; 49(5): 475-479.

White, S.W.; F.M. Traugott and A.W. Quail (1985). Central nervous system 5-hydroxytryptamine and noradrenaline specificity of ear vascular and ventilation reflexes in thermoregulating rabbits. J. Auton. Nev. Syst.; 12: 131-144.

Young, I.S. and J.V. Woodside (2001). Antioxidants in health and disease. J. Clin. Pathol.; 54:176-86.

Young, K.M. R.L. Cramp and C.E. Franklin (2013). Each to their own: skeletal muscles of different function use different biochemical strategies during aestivation at high temperature. J. Exp. Biol., 216: 1012-1024. 
Yuan, W.X.; X.J. Wu; F.X. Yang; X.H. Shang and L.L. Zhang (1989). Effects of ginseng root saponins on brain monoamines and serum corticosterone in heat-stressed mice. Zhongguo. Yao. Li. Xuе. Bao.; 10: 492-496.

Zhang, L.L.; Liu D. Yan; L.Q. Ma; Z.D. Luo; T.B. Cao; J. Zhong; Z.C. Yan; L.J. Wang; Z.G. Zhao; S.J. Zhu; M. Schrader; F. Thilo; Z.M. Zhu and M. Tepel (2007). Activation of transient receptor potential vanilloid type-1 channel prevents adipogenesis and obesity. Circ. Res. ,13: 1063-1070.

Zhao, Y.L.; C. Xing; Z.Z. Lu; L.M. Wang; J.D. Li and Y.Q. Zhao (2001). Effect of heat stress on DA mediated PI signal transduction system in rat striatum. Space Med. Med. Eng. (Beijing); 14: 116-119.

\section{التأثير الوقائي للكابسيسين ضد الإجهاد التأكسدي للمخ الحادث إنباث نتيجة للإجهاد الحراري في أرانب الأبري}

خالد عبد المعبود احمد - و ائل على حسن ـ أحمد أحمد الجمل ـ محمد نادر فكرى

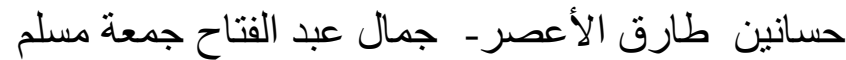

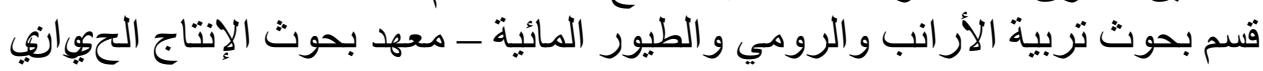

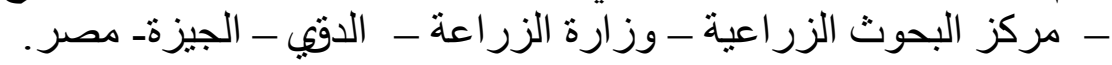

$$
\begin{aligned}
& \text { يسبب الإجهاد الحراري آثنار ضارة منها ما يحفز الإجهاد التأكسدي لغشاء الخلايا }
\end{aligned}
$$

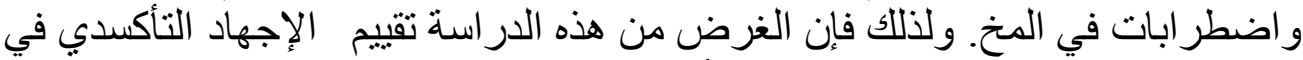

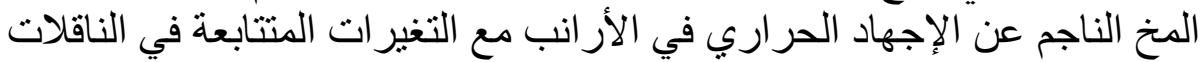

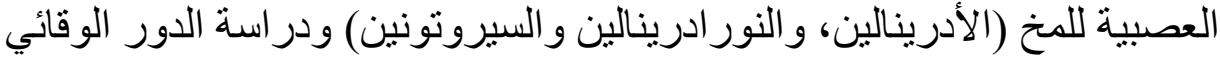

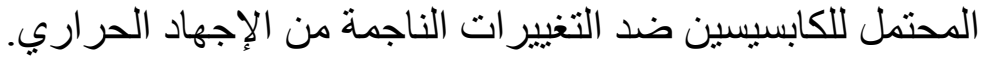

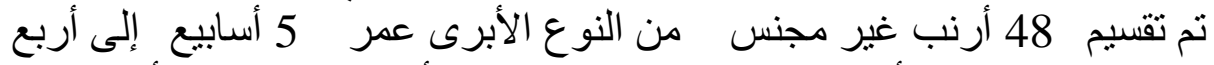

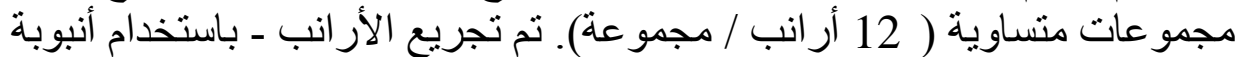

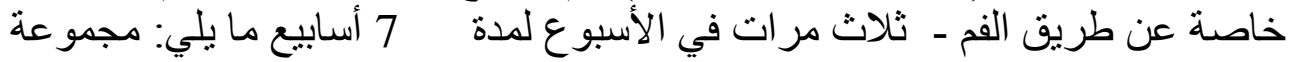

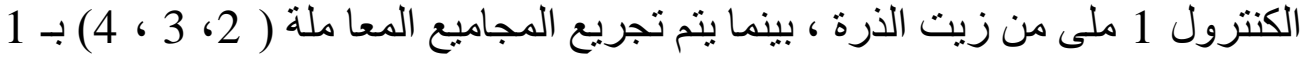


ملى من زيت الذرة مذاب فيه كابسيسين بنسب 10 و 30 و 50 ملجم / كجم من وزن

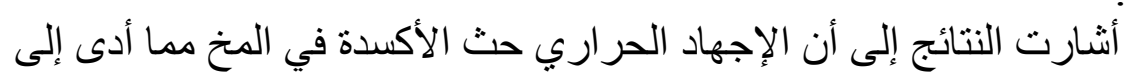

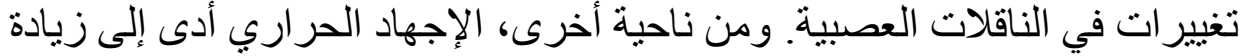

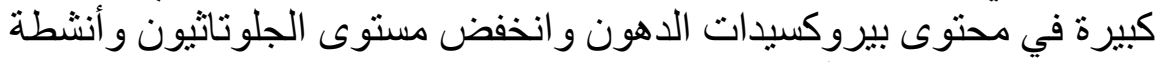

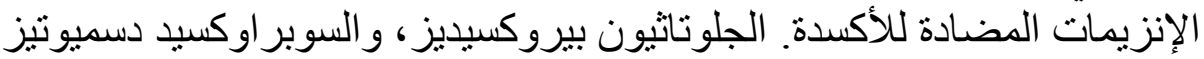

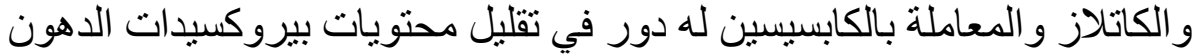

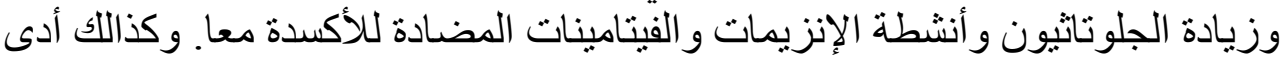

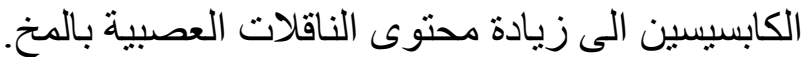

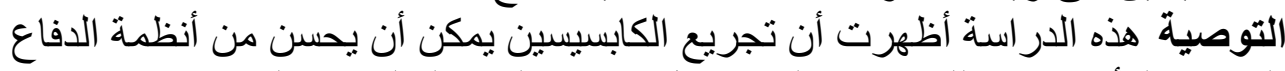
المضادة للأكسدة وكذلك وظيفة المخ خلال حر ارة البيئة العالية فى الصيف. 